\title{
KAJIAN KRITIS KONTRIBUSI SIGNALING THEORY PADA AREA PENELITIAN ONLINE COMMERCE
}

Oleh: Endang Hariningsih ${ }^{1}$ dan Mugi Harsono ${ }^{2}$

${ }^{1}$ Akademi Manajemen Administrasi YPK Yogyakarta

endang.hariningsih@gmail.com

${ }^{2}$ Fakultas Ekonomika dan Bisnis Universitas Sebelas Maret Surakarta

mugiharsono@yahoo.com

\begin{abstract}
Abstrak
Tujuan paper ini memberikan tinjauan kritis dari Signaling Theory dengan konsep-konsep utamanya, serta mengulas penggunaannya dalam penelitian online commerce. Metode yang digunakan dalam studi ini adalah dengan menggunakan kajian pustaka. Tinjauan kritis dilakukan dengan melakukan review penelitian yang menggunakan Signaling Theory sebagai basis teorinya. Signaling Theory berguna untuk menggambarkan perilaku ketika dua pihak (individu atau organisasi) memiliki akses ke informasi yang berbeda, sehingga bisa memunculkan asimetri inforamsi. Dengan demikian, Signaling Theory memegang posisi yang menonjol dalam berbagai literatur Manajemen. Dalam konteks penelitian online commerce, Signaling Theory diwujudkan dalam berbagai signal yang dapat ditangkap dari informasi yang ditampilkan dalam website dengan beragam bentuk lainnya. Oleh karena itu, tinjauan kritis dalam paper ini dapat berkontribusi bagi para peneliti di bidang pemasaran agar dapat mengembangkan penggunaan Signaling Theory khususnya online commerce untuk menggali peluang gap penelitian yang akan datang untuk menggali beragam signal lain yang belum terungkap dan mengembangkan penelitian masa depan yang lebih variatif.
\end{abstract}

Kata kunci: kajian kritis, Signaling Theory, signal, asimetri informasi 


\section{PENDAHULUAN}

Signaling Theory secara fundamental berkaitan dengan pengurangan asimetri informasi antara dua pihak. Menurut Mavlanova, et al. (2012), Teori Signaling membantu menjelaskan perilaku dua pihak ketika mereka memiliki akses ke informasi yang berbeda. Connelly et al. (2011) mengungkapkan pendapat Spence (1978) dalam paper seminal tentang Teori Signaling dalam pasar tenaga kerja yang menunjukkan bagaimana pelamar pekerjaan mampu terlibat mengurangi asimetri informasi yang menghambat kemampuan seleksi calon pemberi kerja.

Kemunculan Signaling Theory dihasilkan dari studi tentang ekonomi informasi dalam kondisi dimana pembeli dan penjual berhubungan dengan infomasi asimetri ketika berinteraksi di pasar. Spence mengilustrasikan bagaimana calon karyawan berkualitas tinggi membedakan dirinya di antara calon karyawan berkualitas rendah dengan menunjukkan signal bahwa dia adalah lulusan dari perguruan tinggi yang berkualitas. Connelly et al., (2011) menambahkan bahwa teori ini digunakan untuk meneliti asimetri informasi antara dua pihak, terjadi sebagai hasil dari disparitas pengetahuan di beragam organisasi dan konteks bisnis. Dalam proses pengambilan keputusan, hal krusial yang diperlukan adalah mendapatkan informasi akurat dari individu, bisnis dan pemerintah. Sehingga seperti yang diungkap oleh Spence (2002), hal ini merupakan fungsi kunci dari signaling Theory untuk mengurangi asimetri dalam informasi.

Sejumlah besar study literatur review telah menerapkan Signaling Theory untuk pengambilan keputusan dalam suatu skenario pemilihan yang terjadi dalam berbagai disiplin ilmu dari antropologi ke zoologi (Bird \& Smith, 2005). Para peneliti area manajemen juga telah menerapkan Signalling Theory untuk membantu menjelaskan pengaruh asimetri informasi dalam beragam disiplin ilmu. Antara lain dalam bidang keuangan (Benartzi, et al., 1997; Robbins \& Schatzberg, 1986), manajemen (Certo, 2003; Turban \& Greening, 1997), pemasaran (Boulding \& Kirmani, 1993; Kirmani, 1997; (Kirmani \& Rao, 2000) (Rao, et al., 1999).

Dengan banyaknya penelitian empiris yang menggunakan Signaling Theory, memicu banyak penulis melakukan review literatur. Connelly et al., (2011) melakukan review literatur tentang penggunaan Signalling Theory Manajemen dalam beragam penelitian. Dalam review tersebut, Connelly et al., (2011) menyarankan bahwa 
para peneliti harus melengkapi review Signaling Theory dengan review di bidang yang lebih spesifik seperti reviews bidang biologi (Smith \& Harper, 1995), anthropology (Bird \& Smith, 2005), ekonomi (Riley, 2001), dan bidang pemasaran (Kirmani \& Rao, 2000) untuk mendapatkan gambaran lengkap yang didapatkan dari konstruk, hubungan, dan proses Signalling Theory. Selanjutnya Karasek \& Bryant, (2012) juga melakukan review dalam area Manajemen Strategi. Dalam penelitian empiris area Manajemen Strategi, Reuber and Fischer, (2009) mengintegrasikan temuan-temuan empiris dari penelitian sebelumnya tentang reputasi dari bidang manajemen strategi, studi organisasi, pemasaran, dan MIS melalui lensa teoritis Teori Signaling berbasis ekonomi. Secara empiris ditemukan bahwa signal reputasi yang dikendalikan perusahaan berupa komitmen yang kredibilitas dalam bentuk harga, iklan, dan umbrella branding.

Dengan adanya internet, telah merubah cara orang mencari informasi (Ho \& Oh, 2009). Alba et al., (1997) menyampaikan bahwa internet menawarkan sejumlah besar informasi dan alat yang membantu pengambilan keputusan untuk mengakses, membandingkan, dan mengevaluasi alternatif. Menurut study Wells, et al., (2011) Teori Signaling dapat memberikan wawasan baru untuk penelitian eCommerce karena kualitas situs web dapat dikonseptualisasikan sebagai isyarat ekstrinsik dan dipertimbangkan secara terpisah dari informasi produk intrinsik yang disampaikan di situs web. Mengingat tantangan unik yang terkait dengan saluran pemasaran eCommerce, (Wells et al., 2011) menyatakan bahwa bahwa Signaling Theory adalah lensa teoretis yang tepat untuk memahami bagaimana dan mengapa kualitas situs web memengaruhi persepsi kualitas produk.

Signaling Theory telah diaplikasikan di konteks online commerce untuk menginvestigasi bagaimana tradisional signal (seperti reputasi, garansi, dan biaya periklanan) mempengaruhi kepercayaan dan persepsi resiko dengan pengecer online (misalnya reputasi, garansi, dan biaya advertising) mempengaruhi kepercayaan dan persepsi risiko dengan pengecer online (Aiken \& Boush, 2006; Biswas \& Biswas, 2004; Wang, Beatty, \& Foxx, 2004; Yen, 2006). Menurut Biswas \& Biswas, (2004) dalam Wells et al., (2011), signal lebih penting di pemasaran online dibandingkan di pemasaran offline. 
Dalam area penelitian pemasaran, review literatur yang menggunakan Signalling Theory telah dilakukan oleh beberapa penulis antara lain meta analisis tentang kredibilitas sumber (Eisend \& Berlin, 1953), signal kualitas produk dan jasa (Erevelles, Roy, \& Yip, 2001), gap signaling Theory (Taj, 2016), keberlanjutan penelitian bidang marketing (Connelly, Ketchen, \& Slater, 2011), pemasaran kesehatan (Fletcher-Brown, et al., 2018). Studi empiris Wells et al., (2011) memasukkan sintesis penelitian pemasaran online dan Sistem Informasi dalam konteks B2C yang menggunakan Signaling Theory. Tetapi hanya diungkap secara ringkas untuk kepentingan mengungkapkan gap teori dan masih kurang dalam mensintesis konstruk yang menggunakan dasar Signaling Theory khususnya konstruk hasil signal. Sehingga, dari beberapa literatur tersebut, ruang lingkup review literatur yang dilakukan masih terbatas dalam obyek tertentu, belum melakukan review secara integratif dan sistematis meliputi semua area bidang penelitian pemasaran khususnya dalam konteks online commerce. Oleh karena itu, paper ini menempatkan gap literatur dengan melakukan review penelitian secara sistematis dan menjelaskan bagaimana para peneliti menerapkan Signaling Theory di bidang pemasaran online.

Sehingga, artikel ini mampu memberikan kontribusi terhadap penelitian manajemen pemasaran menggunakan Signaling Theory. Pertama, kami mengumpulkan dan mensintesis Signaling Theory sebagai konstruk kunci. Kedua, kami memberikan implikasi dan saran bagi penelitian mendatang yang menggunakan Signaling Theory.

Paper diawali dengan (1) Penjelasan bagaimana Signaling Theory bekerja, (2) Mereview konstruk yang digunakan, (3) Mereview penelitian di area online commerce yang menggunakan dasar Teori Signaling, (4) memberikan saran penelitian masa depan di area online commerce yang menggunakan dasar Signaling Theory.

\section{METODE}

Kajian artikel ini disusun secara deskriptif dengan menggunakan kajian literatur yang diperoleh dari berbagai sumber dan teori terkait.

\section{PEMBAHASAN DAN ANALISIS SIGNALING THEORY}

Signaling Theory pertama kali diperkenalkan oleh Spence, (1973) dalam paper seminalnya yang memberikan contoh 
hipotetis tentang bagaimana signaling mempengaruhi pilihan pekerjaan di pasar. Menurut (Spence, 1973), menggambarkan proses perekrutan sebagai investasi dan menyamakannya dengan bermain Lotre. Upah adalah kontribusi marjinal bahwa majikan akan membayar untuk perwakilan dalam Lotre ini. Tetapi sama seperti angka terakhir diambil dalam Lotre, kita tidak tahu sampai itu terjadi apakah kita melakukan investasi yang benar atau tidak. Hal yang tidak pasti atau tidak dapat diobservasi ini dijelaskan dengan baik oleh atribut pribadi yang dapat digambarkan sebagai signal.

Signaling Theory dari Spence, (1973) telah banyak digunakan telah menjadi dasar banyak hipotesis, model, dan ide. Dalam perspektif pemasaran, Kirmani \& Rao, (2000) mengatakan bahwa signaling digunakan pemasar untuk memahami bagaimana konsumen menilai kualitas produk ketika konsumen dihadapkan pada asimetri informasi.

\section{Signal}

Seperti yang diungkapkan oleh (Spence, 1973), signal adalah sesuatu hal yang tidak pasti atau tidak dapat diobservasi. Dalam area pemasaran, signal adalah isyarat yang dapat digunakan oleh penjual untuk menyampaikan informasi kredibel tentang kualitas produk yang tidak dapat diobservasi oleh pembeli (Rao et al., 1999).

Menurut Wells et al., (2011), Signal pada umumnya extrinsic to the product dan lebih percaya diri dinilai oleh konsumen. Isyarat ekstrinsik merupakan atribut ekstrinsik terkait produk yang tidak inherent dalam produk yang dievaluasi, perubahan pada atribut tidak menyebabkan perubahan sifat mendasar dari produk. Sedangkan isyarat intrinsik merupakan atribut produk dimana jika terjadi perubahan, dapat menyebabkan perubahan sifat mendasar dari produk. Misalnya dalam pembelian komputer, harga merupakan isyarat eksternal, sedangkan komponen internal merupakan isyarat intrinsik. Ketika konsumen menggunakan isyarat internal dan eksternal, untuk menilai kualitas produk, isyarat eksternal lebih mudah dipahami konsumen dibandingkan isyarat internal (Dawar \& Parker, 1994) (Zeithaml, 1988). Konsumen dengan waktu terbatas lebih menyukai bergantung pada isyarat eksternal (Zeithaml, 1988). Seperti yang telah ditetapkan sebelumnya, atribut isyarat eksternal digunakan dalam signal dalam merk (Erdem \& Swait, 1998), reputasi pengecer (Chu \& Chu, 1994), harga (Dawar \& Parker, 1994), garansi (Boulding \& 
Kirmani, 1993), lingkungan toko (Baker, et al., 1994; Bloom \& Reve, 1990).

Dalam area online commerce, Mavlanova et al., (2012) menyatakan bahwa ketidakpastian signal yang terkait dengan pembelian online mengarah ke dua masalah asimetri informasi: adverse selection (distorsi informasi yang menghasilkan kesalahan representasi pra-kontrak dari karakteristik penjual yang sesungguhnya) dan moral hazard (timbul di pascakontraktual ketika penjual tidak memenuhi janji mereka atau terlibat dalam kegiatan yang menguntungkan mereka dengan biaya pembeli). Untuk mengevaluasi signal website, Mavlanova et al., (2012) juga mengembangkan kerangka kerja dengan tiga dimensi yaitu: kontinum waktu pembelian (pra pembelian, ketika pembelian, dan pasca pembelian), kemudahan verifikasi, dan signaling cost.

\section{Asimetri Informasi dalam Pemasaran}

Asimetri informasi terjadi ketika "orang berbeda mengetahui hal yang berbeda" (Stiglitz, 2002). Teori Signaling membantu menjelaskan perilaku dua pihak ketika mereka mengakses informasi yang berbeda (Mavlanova et al., 2012). Menurut Connelly, et al., (2011), informasi mempengaruhi proses pengambilan keputusan yang digunakan oleh individu dalam rumah tangga, bisnis, dan pemerintah. Karena beberapa informasi bersifat pribadi, asimetri informasi muncul di antaranya mereka yang memegang informasi itu dan mereka yang berpotensi dapat membuat keputusan yang lebih baik jika mereka memilikinya. Selama lebih dari seabad, model ekonomi formal dari proses pengambilan keputusan adalah berdasarkan pada asumsi informasi yang sempurna, di mana asimetri informasi tersebut berada diabaikan (Stiglitz, 2002). Menurut Stiglitz, (2000), terlepas dari ketidaksempurnaan informasi yang terjadi, para ekonom sebagian besar berasumsi bahwa pasar dengan ketidaksempurnaan informasi kecil akan berperilaku sama seperti pasar dengan informasi yang sempurna.

Dalam area pemasaran, Kirmani \& Rao, (2000) menyatakan bahwa asimetri informasi dapat didiskripsikan sebagai kelangkaan (scarcity) informasi pra pembelian dan kelangkaaan kejelasan (clarity) informasi pasca pembelian. Wells et al., (2011) menyatakan bahwa kelangkaan informasi pra pembelian terjadi karena konsumen sebelumnya tidak dapat mengakses atau menginterpretasi atribut kualitas produk untuk membuat keputusan. Sedangkan kelangkaan kejelasan informasi 
pasca pembelian artinya konsumen tidak segera dapat mengetahui kualitas produk setelah pembelian. Sebagai contoh, pembelian baju secara online memiliki tingkat kelangkaan pra pembelian yang tinggi karena konsumen tidak dapat segera secara fisik mencoba sebelum melakukan pembelian. Setelah menerima dan mencoba baju, konsumen memiliki kelangkaan kejelasan informasi karena sesuai atau tidaknya baju, sudah terlanjur terjadi pembelian. Scarcity dan clarity informasi dapat beragam tergantung pada sifat produk dan pengalaman konsumen.

Stiglitz, (2000) mengelompokkan dua tipe asimetri informasi dapat terjadi dalam informasi tentang kualitas dan informasi tentang niat. Dalam kasus pertama, asimetri informasi penting ketika satu pihak tidak sepenuhnya menyadari karakteristik pihak lain. Dalam kasus kedua, informasi asimetri juga penting ketika satu pihak memberi perhatian terhadap perilaku atau niat perilaku pihak lain. Merujuk pada pendapat (Darby \& Karni, 1973) dan (Nelson, 1970), menyatakan bahwa terdapat tiga penggolongan produk untuk membedakan tingkat asimetri informasi, yaitu: search good, experience good, dan credence good.

Kategori produk dalam golongan search good yaitu ketika memiliki tingkat scarcity informasi pra pembelian dan clarity informasi pasca pembelian. Hal ini terjadi ketika pembelian produk tidak membutuhkan pengujian secara fisik sebelum pembelian (misalnya buku). Tetapi, kebalikannya untuk experience good menempatkan tingkat scarcity informasi pra pembelian yang tinggi dan membutuhkan pengalaman dan penggunaan langsung untuk memastikan kualitas (Nelson, 1970).

Pengalaman atas produk didapatkan melalui produk ketika pra dan pasca pembelian sehingga memungkinkan konsumen mendapat kejelasan atas kualitas produk yang akan dan sudah dibeli. Untuk golongan credence good, menilai kualitas produk yang tidak mudah dipastikan secara langsung ketika pasca pembelian (misalnya reparasi mobil) (Darby \& Karni, 1973). Ketersediaan informasi produk dapat berubah berdasarkan pengalaman konsumen dan saluran pemasaran (Klein, 1998). Misalnya, dalam pembelian pakaian secara berulang secara online, seorang konsumen memiliki pengalaman produk langsung berdasarkan pembelian sebelumnya, dan item pakaian itu sekarang menjadi kelompok search good untuk konsumen tersebut. Selanjutnya, item pakaian yang dikategorikan sebagai kelompok search good di lingkungan toko tradisional, 
mungkin menjadi lebih baik disebut sebagai kelompok experience good dalam saluran pemasaran online yang tidak menyediakan uji coba sebelum pembelian.

\section{Kredibilitas Signal}

Boulding \& Kirmani, menyatakan bahwa suatu signal dikatakan dapat dipercaya ketika sejumlah kekayaan, investasi, atau reputasi akan hangus oleh penjual jika mereka mengirim signal palsu dan menjual produk berkualitas rendah. Wells et al., (2011) menyampaikan bahwa garansi adalah salah satu contoh signal yang kredibel. Jika penjual memberikan produk berkualitas rendah dengan garansi, penjual akan dikenakan biaya perbaikan atau penggantian saat pembeli mengajukan klaim garansi.

Penjual produk-produk berkualitas tinggi tidak akan dikenakan biaya garansi yang sama. Kekayaan atau aset yang akan hangus karena mengirimkan signal palsu sering disebut sebagai ikatan, atau bentuk asuransi kepada pembeli bahwa penjual akan menyediakan produk berkualitas tinggi. Kredibilitas signal juga disebut sebagai kredibilitas obligasi, adalah kondisi teoretis kunci bagi signal untuk menjadi mekanisme yang efektif untuk menyampaikan kualitas produk yang tinggi.
Signal tinggi atau kredibilitas obligasi terjadi ketika konsumen percaya bahwa penjual melakukan investasi signifikan dengan mengirimkan signal dan investasi berisiko jika signal palsu dikirimkan. Oleh karena itu, signal palsu menjadi terlarang untuk penjual produk berkualitas rendah. Sehingga, hanya penjual dengan produk berkualitas tinggi yang mampu mengirim signal kredibilitas tinggi, yang memungkinkan pembeli untuk membedakan antara penjual produk berkualitas tinggi dan rendah (Boulding \& Kirmani, 1993).

Selanjutnya (Wells et al., 2011) menyimpulkan bahwa Signaling Theory paling sesuai diterapkan ketika konsumen mempersepsikan bahwa penjual telah membuat investasi substansial dalam mengirimkan signal kualitas tinggi dan hal ini beresiko ketika signal yang dikirimkan tersebut salah.

\section{Hasil Signal}

Hasil yang diinginkan dalam kerangka kerja signaling adalah untuk signal untuk mengurangi kesenjangan informasi, memastikan pihak yang kurang informasi (mis., pembeli) bahwa mereka memilih produk atau layanan berkualitas baik (Bloom \& Reve, 1990). Tujuan akhir dari signaling adalah untuk secara positif 
memengaruhi hasil yang diinginkan seperti persepsi kualitas (mis., produk, jasa, pelamar pekerjaan, stok, dll.) dan perilaku (mis. niat beli, niat merekrut, dll.) (Wells et al., 2011). Paper ini menambahkan konstruk dependent yang merupakan hasil signal berupa willingness to pay premium juga bias menjadi tujuan akhir dari signaling (Chu \& Chu, 1994); Leischnig \& Enke,
(2011); Gregg \& Walczak, (2010); Calvo Dopico et al., (2016); Liu \& Hu, (2011).

Ringkasan konstruk dalam Signaling Theory yang digunakan dalam penelitian empiris dapat dilihat di tabel 1 yang terdiri dari konstruk signal, asimetri informasi, kredibilitas signal, dan hasil signal.

Tabel 1. Konstruk dalam Signaling Theory

\begin{tabular}{|c|c|c|c|c|}
\hline & Signal & $\begin{array}{c}\text { Asimetri } \\
\text { informasi }\end{array}$ & $\begin{array}{c}\text { Kredibilitas } \\
\text { signal }\end{array}$ & Hasil signal \\
\hline \multirow[t]{2}{*}{ Deskripsi } & $\begin{array}{l}\text { - Isyarat } \\
\text { informasional } \\
\text { - Ekstrinsik } \\
\text { terhadap } \\
\text { internal interest } \\
\text { - High confidence } \\
\text { value }\end{array}$ & $\begin{array}{l}\text { - } \text { Keberadaan } \\
\text { asimetri } \\
\text { informasi } \\
\text { - Kelangkaan } \\
\text { informasi pra } \\
\text { pembelian } \\
\text { (scarcity) } \\
\text { - Kurangnya } \\
\text { kejelasan } \\
\text { informasi pasca } \\
\text { pembelian } \\
\text { (clarity) }\end{array}$ & $\begin{array}{l}\text { - Signal } \\
\text { membutuhkan } \\
\text { investasi atau } \\
\text { jaminan (bond). } \\
\text { - Investasi } \\
\text { (jaminan) harus } \\
\text { vulnerable } \\
\text { - Subyektif }\end{array}$ & 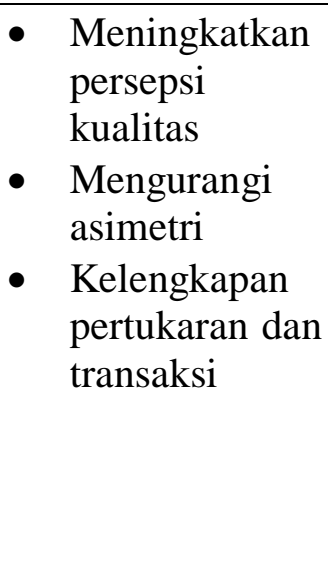 \\
\hline & $\begin{array}{l}\text { - Harga } \\
\text { - Advertensi } \\
\text { - Garansi } \\
\text { - Merk } \\
\text { - Lingkungan } \\
\text { toko }\end{array}$ & $\begin{array}{l}\text { Pengalaman } \\
\text { produk dan jasa } \\
\text { (missal: pakaian, } \\
\text { mobil, makanan) }\end{array}$ & 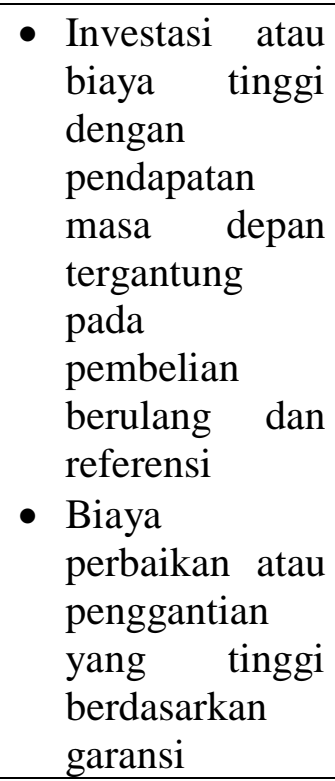 & $\begin{array}{l}\text { - Kualitas produk } \\
\text { dan jasa } \\
\text { - Kualitas merk } \\
\text { - Pengurangan } \\
\text { ketidakpasian } \\
\text { - Kepercayaan } \\
\text { - Niat pembelian } \\
\text { atau transaksi } \\
\text { - Willingness to } \\
\text { pay premium }\end{array}$ \\
\hline
\end{tabular}




\section{PENELITIAN AREA ONLINE COMMERCE DENGAN SIGNALING THEORY}

Adanya online commerce menawarkan perusahaan dengan beragam keuntungan (misalnya dapat menjangkau lebih banyak konsumen, meningkatkan availability, aksesibilitas informasi), tetapi online commerce juga mendatangkan banyak tantangan (Wells et al., 2011). Dalam online commerce, signaling diwujudkan dalam tampilan website yang menawarkan informasi dari penjual kepada pembeli (Mavlanova et al., 2012). Para penjual dalam online commerce dapat mengontrol informasi yang mereka berikan dengan melebih-lebihkan kualitas. Sehingga beberapa produk di online commerce yang berkualitas rendah yang dijual tidak dapat dibedakan dari produk yang berkualitas tinggi. Tabel 2 berikut menampilkan ringkasan penelitian empiris di area online commerce $\mathrm{B} 2 \mathrm{C}$ yang menggunakan dasar Signaling Theory.

\section{Tabel 2. Penelitian Empiris di Area Online Commerce} yang menggunakan dasar Signaling Theory

\begin{tabular}{|c|c|c|}
\hline Jurnal & Author & Signal \\
\hline $\begin{array}{l}\text { Journal of the Academy of } \\
\text { Marketing Science }\end{array}$ & Aiken \& Boush, (2006) & $\begin{array}{l}\text { - trust marks } \\
\text { - objective-source ratings } \\
\text { - advertising investme }\end{array}$ \\
\hline $\begin{array}{l}\text { Journal of Interactive } \\
\text { Marketing }\end{array}$ & Biswas \& Biswas, (2004) & $\begin{array}{l}\text { - retailer reputation } \\
\text { - advertising expense } \\
\text { - warranties }\end{array}$ \\
\hline $\begin{array}{l}\text { Journal of Management } \\
\text { Information Systems }\end{array}$ & Bolton et al., (2008) & kepercayaan \\
\hline $\begin{array}{l}\text { Journal of Management } \\
\text { Information System }\end{array}$ & Bolton, et al., (2008) & $\begin{array}{l}\text { kompetisi } \\
\text { network }\end{array}$ \\
\hline $\begin{array}{l}\text { Journal of Consumer } \\
\text { Behavior }\end{array}$ & Bu \& Go, (2008) & kepercayaan \\
\hline $\begin{array}{l}\text { Journal of Interactive } \\
\text { Marketing }\end{array}$ & Casado-Aranda, et al., (2019) & kepercayaan \\
\hline Online Information Review & Chang et al., (2013) & tipe produk \\
\hline Marketing Science & Chu \& Chu, (1994) & signaling quality \\
\hline $\begin{array}{l}\text { International Journal of } \\
\text { Electronic Commerce }\end{array}$ & Chu et al., (2005) & $\begin{array}{l}\text { - infomediary reputation } \\
\text { - manufactur, retail brand }\end{array}$ \\
\hline $\begin{array}{l}\text { Journal of Information } \\
\text { System }\end{array}$ & Durcikova \& Gray, (2008) & \\
\hline
\end{tabular}




\begin{tabular}{|c|c|c|}
\hline Jurnal & Author & Signal \\
\hline $\begin{array}{l}\text { International Journal of } \\
\text { Electronic Commerce }\end{array}$ & Gregg \& Scott, (2006) & $\begin{array}{l}\text { online reputation system } \\
\text { (feedback rating) }\end{array}$ \\
\hline MIS Quarterly & Gregg \& Walczak, (2008) & $\begin{array}{l}e \text {-image (nama bisnis, } \\
\text { lelang, atribut website) }\end{array}$ \\
\hline $\begin{array}{l}\text { Electronic } \quad \text { Commerce } \\
\text { Research }\end{array}$ & Gregg \& Walczak, (2010) & $\begin{array}{l}\text { - website } \\
\text { - kepercayaan } \\
\text { - harga premium }\end{array}$ \\
\hline $\begin{array}{l}\text { International Conference } \\
\text { Information System }\end{array}$ & Gwee, et al., (2002) & Intensitas advertising \\
\hline $\begin{array}{l}\text { Journal of Computer } \\
\text { Information System }\end{array}$ & Hill, et al., (2017) & vlogger \\
\hline Online Information Review & Ho \& Oh, (2009) & e-security seal \\
\hline $\begin{array}{l}\text { International Journal of } \\
\text { Electronic Marketing and } \\
\text { Retailing }\end{array}$ & Hou, (2007) & harga \\
\hline $\begin{array}{l}\text { Journal of Management } \\
\text { Information System }\end{array}$ & Hoxmeier, (2000) & $\begin{array}{l}\text { software preannouncement } \\
\text { (kredibilitas waktu } \\
\text { pengiriman, } \\
\text { reliabilitas/feature } \\
\text { software) }\end{array}$ \\
\hline $\begin{array}{l}\text { International Journal of } \\
\text { Internet Marketing and } \\
\text { Advertising }\end{array}$ & Kim \& Choi, (2012) & $\begin{array}{l}\text { kualitas produk } \\
\text { persepsi resiko }\end{array}$ \\
\hline $\begin{array}{l}\text { Journal of the Association } \\
\text { for Information Systems }\end{array}$ & Kim et al., (2004) & $\begin{array}{l}\text { - } \text { reputasi } \\
\text { - kualitas website (kualitas } \\
\text { informasi dan kualitas } \\
\text { website) }\end{array}$ \\
\hline MIS Quarterly & Kimery \& McCord, (2011) & $\begin{array}{l}\text { Jaminan (assurance seal) } \\
\text { pihak ketiga }\end{array}$ \\
\hline $\begin{array}{l}\text { Journal of Economic } \\
\text { Psychology }\end{array}$ & Lee, et al., (2005) & kepercayaan \\
\hline $\begin{array}{l}\text { Journal of Product and } \\
\text { Brand Management }\end{array}$ & Liu \& Hu, (2011) & umbrella brand \\
\hline Decision Support Systems & Ma, et al., (2012) & rating \\
\hline MIS Quarterly & Pavlou \& Liang, (2007) & $\begin{array}{l}\text { - kepercayaan, social } \\
\text { presence } \\
\text { - informasi website } \\
\text { - diagnosa produk } \\
\text { - keterlibatan pembelian }\end{array}$ \\
\hline Decision Science & Rao, et al., (2018) & merchandise return policy \\
\hline $\begin{array}{l}\text { International Journal of } \\
\text { Information Management }\end{array}$ & Rekik, et al., (2018) & kualitas website \\
\hline $\begin{array}{l}\text { International Journal of } \\
\text { Electronic Commerce }\end{array}$ & $\mathrm{Su},(2007)$ & $\begin{array}{l}\text { - harga } \\
\text { - rating }\end{array}$ \\
\hline
\end{tabular}




\begin{tabular}{|c|c|c|}
\hline Jurnal & Author & Signal \\
\hline & & $\begin{array}{l}\text { - korelasi dengan } \\
\text { kredibilitas merk }\end{array}$ \\
\hline Decision Support Systems & Venkatesan, et al., (2006) & retailer service quality \\
\hline MIS Quarterly & Wang et al., (2004) & kepercayaan \\
\hline $\begin{array}{l}\text { Journal of Interactive } \\
\text { Marketing }\end{array}$ & Wang et al., (2004) & $\begin{array}{l}\text { - seal approval } \\
\text { - kebijakan pengembalian, } \\
\text { award } \\
\text { - Keamanan, privasi }\end{array}$ \\
\hline MIS Quarterly & Wells et al., (2011) & kualitas website \\
\hline $\begin{array}{l}\text { International Journal of } \\
\text { Internet Marketing and } \\
\text { Advertising }\end{array}$ & Yen, (2006) & $\begin{array}{l}\text { - endorsement pihak } \\
\text { ketiga } \\
\text { - keberadaan toko fisik } \\
\text { - kejelasan garansi }\end{array}$ \\
\hline $\begin{array}{l}\text { Journal of Computational } \\
\text { Science }\end{array}$ & Zhang, et al., (2018) & $\begin{array}{l}\text { - keamanan } \\
\text { - kepercayaan }\end{array}$ \\
\hline
\end{tabular}


Berdasarkan Tabel 2, dapat disimpulkan bahwa terdapat tema-tema menonjol yang menjadi isu mayor berupa signal yang menjadi tema penelitian yaitu tentang kepercayaan, harga, kualitas, dan garansi. Selain tema tersebut, isu lain menjadi tema minor yang sangat beragam.

\section{PENUTUP DAN SIMPULAN}

Signaling Theory memberikan keunikan, praktis, dan perspektif yang dapat diuji secara empiris tentang masalah seleksi sosial dalam kondisi informasi yang tidak sempurna. Dalam review paper ini, kami melakukan tinjauan kritis tentang bagaimana bekerjanya Signaling Theory terutama dalam area penelitian bidang pemasaran khususnya online commerce, dengan merangkum konstruk yang digunakan dalam penelitian dan menampilkan beragam penelitian dengan beragam jenis signal yang menjadi obyek penelitian online commerce.

Para peneliti ke depan dapat mengeksplorasi menggunaan Signaling Theory untuk dijadikan basis teori dalam beragam penelitian serta untuk pengembangan teori lebih lanjut. Beberapa penelitian empiris yang perlu dilakukan untuk mengungkap area pengembangan Signaling Theory di bidang jasa online yang juga terjadi asimetri informasi. Selain itu perlu dilakukan penelitian lain dengan mengungkap signal yang belum diungkap oleh penelitian sebelumnya misalnya biaya pengiriman, frekuensi bertanya, frekuensi mengunjungi website, word of mouth, komentar dalam bentuk kualitatif, perilaku konsumen lainnya yang dapat terekam dalam cookies website, dan lain-lain yang dapat bermanfaat dalam pengambilan keputusan pemasar online dalam beragam keputusan strategi.

\section{DAFTAR PUSTAKA}

\section{Jurnal}

Aiken, K. D., \& Boush, D. M. (2006). Trustmarks, objective-source ratings, and implied investments in advertising: Investigating online trust and the contextspecific nature of internet signals. Journal of the Academy of Marketing Science, 34(3), 308-323. https://doi.org/10.1177/0092070304271004

Alba, J., Lynch, J., Weitz, B., Janiszewski, C., Lutz, R., Sawyer, A., \& Wood, S. (1997). Interactive home shopping: Consumer, retailer, and manufacturer incentives to participate in electronic marketplaces. Journal of Marketing, 61(3), 38-53. https://doi.org/10.2307/1251788

Baker, J., Grewal, D., \& Parasuraman, A. (1994). The influence of store environment on quality inferences and store image. Journal of the Academy of Marketing Science: Official Publication of the Academy of Marketing Science, 22(4), 328339. https://doi.org/10.1177/0092070394224002

Benartzi, Shlomo, Michaely Rony, and Thaler, R. (1997). Do Changes in Dividends Signal the Future or the Past? CFA Digest, 28(1), 45-47.

https://doi.org/10.2469/dig.v28.n1.219

Bentley, T., Chan, T. Y., \& Park, Y. (2015). Testing the Signaling Theory of Advertising: Evidence from Search Advertisements. (January).

Bird, R. B., \& Smith, E. A. (2005). Signaling Theory, strategic interaction, and symbolic capital. Current Anthropology, 46(2), 221248. https://doi.org/10.1086/427115

Biswas, D., \& Biswas, A. (2004). The diagnostic 
role of signals in the context of perceived risks in online shopping: Do signals matter more on the web? Journal of Interactive Marketing, 18(3), 30-45. https://doi.org/10.1002/dir.20010

Bloom, P. N., \& Reve, T. (1990). Transmitting signals to consumers for competitive advantage. Business Horizons, 33(4), 58$66 . \quad$ https://doi.org/10.1016/00076813(90)90059-K

Bolton, G., Loebbecke, C., \& Ockenfels, A. (2008). Does competition promote trust and trustworthiness in Online trading? An experimental study. Journal of Management Information Systems, 25(2), 145-169. https://doi.org/10.2753/MIS07421222250207

Boulding, W., \& Kirmani, A. (1993). A Consumer-Side Experimental Examination of Signaling Theory: Do Consumers Perceive Warranties as Signals of Quality? Journal of Consumer Research, 20(1), 111. https://doi.org/10.1086/209337

Bu, O. B., \& Go, A. S. (2008). Perceived trustworthiness of online shops. Journal of Consumer Behaviour, 50(October), 35-50. https://doi.org/10.1002/cb

Calvo Dopico, D., Mendes, R., Silva, H. A., Verrez-Bagnis, V., Pérez-Martín, R., \& Sotelo, C. G. (2016). Evaluation, signaling and willingness to pay for treaceability. A cross-national comparison. Spanish Journal of Marketing - ESIC, 20(2), 93-103. https://doi.org/10.1016/j.sjme.2016.07.001

Casado-Aranda, L. A., Dimoka, A., \& SánchezFernández, J. (2019). Consumer Processing of Online Trust Signals: A Neuroimaging Study. Journal of Interactive Marketing, 47, 159-180.

https://doi.org/10.1016/j.intmar.2019.02.00 6

Certo, S. T. (2003). Influencing initial public offering investors with prestige: Signaling with board structures. Academy of Management Review, 28(3), 432-446. https://doi.org/10.5465/AMR.2003.1019675 4

Chang Lee, K., Gurrea, R., Orús, C., \& Flavián,
C. (2013). The role of symbols signalling the product status on online users' information processing. Online Information Review, 37(1), 8-27. https://doi.org/10.1108/1468452131131160 3

Chu, W., Choi, B., \& Song, M. R. (2005). The role of on-line retailer brand and infomediary reputation in increasing consumer purchase intention. International Journal of Electronic Commerce, 9(3), 115-127.

https://doi.org/10.1080/10864415.2005.110 44336

Chu, W., \& Chu, W. (1994). Signaling Quality by Selling Through a Reputable Retailer: An Example of Renting the Reputation of Another Agent. Marketing Science, 13(2), 177-189. https://doi.org/10.1287/mksc.13.2.177

Connelly, B. L., Certo, S. T., Ireland, R. D., \& Reutzel, C. R. (2011). Signaling Theory: A review and assessment. Journal of Management, 37(1), 39-67. https://doi.org/10.1177/0149206310388419

Connelly, B. L., Ketchen, D. J., \& Slater, S. F. (2011). Toward a "theoretical toolbox" for sustainability research in marketing. Journal of the Academy of Marketing Science, 39(1), 86-100. https://doi.org/10.1007/s11747-010-0199-0

Darby, M. R., \& Karni, E. (1973). Free Competition and the Optimal Amount of Fraud. The Journal of Law and Economics, $16(1)$, 67-88. https://doi.org/10.1086/466756

Dawar, N., \& Parker, P. (1994). Marketing Universals: Consumers' Use of Brand Name, Price, Physical Appearance, and Retailer Reputation as Signals of Product Quality. Journal of Marketing, 58(2), 81. https://doi.org/10.2307/1252271

Durcikova, A., \& Gray, P. (2008). How knowledge validation processes affect knowledge contribution. Journal of Management Information Systems, 25(4), 81-107. https://doi.org/10.2753/MIS07421222250403 
Eisend, M., \& Berlin, F. U. (1953). Is it Still Worth to be Credible? A Meta-Analysis of Temporal Patterns of Source Credibility Effects in Marketing. Advances in Consumer Research, 31, 352-357.

Erdem, T., \& Swait, J. (1998). Brand equity as a signaling phenomenon. Journal of Consumer Psychology, 7(2), 131-157. https://doi.org/10.1207/s15327663jcp0702_ 02

Erevelles, S., Roy, A., \& Yip, L. S. C. (2001). The universality of the signal Theory for products and services. Journal of Business Research, 52(2), 175-187. https://doi.org/10.1016/S01482963(99)00069-7

Fletcher-Brown, J., Pereira, V., \& Nyadzayo, M. W. (2018). Health marketing in an emerging market: The critical role of signaling Theory in breast cancer awareness. Journal of Business Research, 86(June 2017), 416-434. https://doi.org/10.1016/j.jbusres.2017.05.03 1

Gregg, D. G., \& Scott, J. E. (2006). The role of reputation systems in reducing on-line auction fraud. International Journal of Electronic Commerce, 10(3), 95-120. https://doi.org/10.2753/JEC10864415100304

Gregg, D. G., \& Walczak, S. (2008). Dressing your online auction business for success: An experiment comparing two ebay businesses. MIS Quarterly: Management Information Systems, 32(3), 653-670. https://doi.org/10.2307/25148860

Gregg, D. G., \& Walczak, S. (2010). The relationship between website quality, trust and price premiums at online auctions. Electronic Commerce Research, 10(1), 125. https://doi.org/10.1007/s10660-0109044-2

Gwee, Y.-T., Hui, K.-L., \& Chau, P. (2002). Determinants of Brand Equity in EBusinesses: An Exploratory Study. International Conference on Information Systems, 617-627. Retrieved from http://aisel.aisnet.org/icis2002\%0Ahttp://ais el.aisnet.org/icis2002/57
Hill, S. R., Troshani, I., \& Chandrasekar, D. (2017). Signalling Effects of Vlogger Popularity on Online Consumers. Journal of Computer Information Systems, O0(00), $1-9$.

https://doi.org/10.1080/08874417.2017.140 0929

Ho, B. C. T., \& Oh, K. B. (2009). An empirical study of the use of e-security seals in ecommerce. Online Information Review, 33(4), 655-671. https://doi.org/10.1108/1468452091098566 6

Hou, J. (2007). Sellers' quality claims in online auctions: Evidence from eBay. International Journal of Electronic Marketing and Retailing, 1(4), 355-369. https://doi.org/10.1504/IJEMR.2007.01484 9

Hoxmeier, J. A. (2000). Software preannouncements and their impact on customers' perceptions and vendor reputation. Journal of Management Information Systems, 17(1), 115-139. https://doi.org/10.1080/07421222.2000.110 45635

Karasek, R., \& Bryant, P. (2012). Signaling Theory: Past, present, and future. Academy of Strategic Management Journal, 11(1), 91-100.

Kim, H.-W., Xu, Y., \& Koh, J. (2004). A Comparison of Online Trust Building Factors between Potential Customers and Repeat Customers. Journal of the Association for Information Systems, 5(10), 392-420. https://doi.org/10.17705/1 jais.00056

Kim, S., \& Choi, S. M. (2012). Credibility cues in online shopping: An examination of corporate credibility, retailer reputation, and product review credibility. International Journal of Internet Marketing and Advertising, $\quad 7(3), \quad$ 217-236. https://doi.org/10.1504/IJIMA.2012.047425

Kimery, K. M., \& McCord, M. (2011). Signals of Trustworthiness in E-Commerce. Journal of Electronic Commerce in Organizations, 4(4), 52-74. https://doi.org/10.4018/jeco.2006100103 
Kirmani, A. (1997). Advertising repetition as a signal of quality: If it's advertised so much, something must be wrong. Journal of Advertising, 26(3), 77-86. https://doi.org/10.1080/00913367.1997.106 73530

Kirmani, A., \& Rao, A. R. (2000). No pain, no gain: A critical review of the literature on signaling unobservable product quality. Journal of Marketing, 64(2), 66-79. https://doi.org/10.1509/jmkg.64.2.66.18000

Klein, L. R. (1998). Evaluating the Potential of Interactive Media through a New Lens: Search versus Experience Goods. Journal of Business Research, 41(3), 195-203. https://doi.org/10.1016/S01482963(97)00062-3

Lee, B. C., Ang, L., \& Dubelaar, C. (2005). Lemons on the Web: A signalling approach to the problem of trust in Internet commerce. Journal of Economic Psychology, 26(5), 607-623. https://doi.org/10.1016/j.joep.2005.01.001

Leischnig, A., \& Enke, M. (2011). Brand stability as a signaling phenomenon - An empirical investigation in industrial markets. Industrial Marketing Management, 40(7),

1116-1122. https://doi.org/10.1016/j.indmarman.2011.0 9.001

Liu, X., \& Hu, M. Y. (2011). Umbrella brand price premiums: Effects of compatibility, similarity, and portfolio size. Journal of Product and Brand Management, 20(1), 58-64.

https://doi.org/10.1108/1061042111110802 1

Ma, Z., Sheng, O. R. L., Pant, G., \& Iriberri, A. (2012). Can visible cues in search results indicate vendors' reliability? Decision Support Systems, 52(3), 768-775. https://doi.org/10.1016/j.dss.2011.12.002

Mavlanova, T., Benbunan-Fich, R., \& Koufaris, M. (2012). Signaling Theory and information asymmetry in online commerce. Information and Management, 49(5), 240-247. https://doi.org/10.1016/j.im.2012.05.004
Nelson, P. (1970). Information and Consumer Behavior. Journal of Political Economy, $78(2)$, 311-329. https://doi.org/10.1086/259630

Pavlou, Liang, \& X. (2007). Understanding and Mitigating Understanding Online Exchange Relationships: Agent Perspective1 A Principal. MIS Quarterly, 31(1), 105-136.

Rao, A. R., Qu, L., \& Ruekert, R. W. (1999). Signaling unobservable product quality through a brand ally. Journal of Marketing Research, 36(2), 258-268. https://doi.org/10.2307/3152097

Rao, S., Lee, K. B., Connelly, B., \& Iyengar, D. (2018). Return Time Leniency in Online Retail: A Signaling Theory Perspective on Buying Outcomes. Decision Sciences, 49(2), 275-305. https://doi.org/10.1111/deci.12275

Rekik, R., Kallel, I., Casillas, J., \& Alimi, A. M. (2018). Assessing web sites quality: A systematic literature review by text and association rules mining. International Journal of Information Management, 38(1), 201-216. https://doi.org/10.1016/j.ijinfomgt.2017.06. 007

Reuber and Fischer. (2009). Signalling Reputation in International Online Markets. Strategic Entrepreneurship Journal, 3, 369-386. https://doi.org/10.1002/sej

Riley, J. G. (2001). Silver signals: Twenty-five years of screening and signaling. Journal of Economic Literature, 39(2), 432-478. https://doi.org/10.1257/jel.39.2.432

Robbins, E. H., \& Schatzberg, J. D. (1986). Callable Bonds: A Risk-Reducing Signalling Mechanism. The Journal of Finance, 41(4), 935. https://doi.org/10.2307/2328238

Schöndienst, V., Kulzer, F., \& Günther, O. (2012). Like versus dislike: How Facebook's like-button influences people's perception of product and service quality. International Conference on Information Systems, ICIS 2012, 1, 439-454.

Smith, M. J., \& Harper, D. G. C. (1995). Animal signals: Models and terminology. Journal of 
Theoretical Biology, 177(3), 305-311. https://doi.org/10.1006/jtbi.1995.0248

Spence, M. (1973). Job Market Signaling. In Uncertainty in Economics (Vol. 87). https://doi.org/10.1016/b978-0-12-214850$7.50025-5$

Spence, M. (2002). Signaling in retrospect and the informational structure of markets. American Economic Review, 92(3), 434459.

https://doi.org/10.1257/0002828026013620 0

Stiglitz, J. E. (2000). The contributions of the economics of information to twentieth century economics. Quarterly Journal of Economics, 115(4), 1441-1478. https://doi.org/10.1162/003355300555015

Stiglitz, J. E. (2002). Information and the Change in the Paradigm in Economics. New Frontiers in Economics, 27-67. https://doi.org/10.1017/CBO978051175435 7.004

$\mathrm{Su}$, B. C. (2007). Consumer e-tailer choice strategies at on-line shopping comparison sites. International Journal of Electronic Commerce, 11(3), 135-159. https://doi.org/10.2753/JEC10864415110305

Taj, S. A. (2016). Application of signaling Theory in management research: Addressing major gaps in Theory. European Management Journal, 34(4), 338-348. https://doi.org/10.1016/j.emj.2016.02.001

Turban, D. B., \& Greening, D. W. (1997). Corporate Social Performance And Organizational Attractiveness To Prospective Employees. Academy of
Management Journal, 40(3), 658-672. https://doi.org/10.5465/257057

Venkatesan, R., Mehta, K., \& Bapna, R. (2006). Understanding the confluence of retailer characteristics, market characteristics and online pricing strategies. Decision Support Systems, 42(3), 1759-1775. https://doi.org/10.1016/j.dss.2006.03.012

Wang, S., Beatty, S. E., \& Foxx, W. (2004). Signaling the trustworthiness of small online retailers. Journal of Interactive Marketing, 18(1), 53-69. https://doi.org/10.1002/dir.10071

Wells, J. D., Valacich, J. S., \& Hess, T. J. (2011). What signal are you sending? How website quality influences perceptions of product quality and purchase intentions. MIS Quarterly: Management Information Systems, $\quad 35(2), \quad 373-396$. https://doi.org/10.2307/23044048

Yen, H. J. R. (2006). Risk-reducing signals for new online retailers: A study of single and multiple signalling effects. International Journal of Internet Marketing and Advertising, 3(4), 299-317. https://doi.org/10.1504/IJIMA.2006.012685

Zeithaml, V. A. (1988). Consumer Perceptions of Price, Qualitye. Journal of Marketing, 52(3),

$2-22$. https://doi.org/10.2307/1251446

Zhang, Z., Wen, J., Wang, X., \& Zhao, C. (2018). A novel crowd evaluation method for security and trustworthiness of online social networks platforms based on Signaling Theory. Journal of Computational Science, 26, 468-477. https://doi.org/10.1016/j.jocs.2017.05.018 